\title{
Morphological Characterization of Drupes Reveals a Higher Diversity of Phyllanthus emblica Germplasm in Anuradhapura, Kandy and Kurunegala Districts of Sri Lanka
}

\author{
S.M.U.P. Mawalagedera ${ }^{1}$, G.A.D. Perera ${ }^{2}$ and S.D.S.S. Sooriyapathirana ${ }^{1^{*}}$ \\ ${ }^{1}$ Department of Molecular Biology and Biotechnology, University of Peradeniya, Sri Lanka. \\ ${ }^{2}$ Department of Botany, University of Peradeniya, Sri Lanka. \\ Accepted April 26, 2014
}

\begin{abstract}
Phyllanthus emblica L. is a commercially important fruit species and its plant parts are indispensable in indigenous herbal medicine. A total of 475 P. emblica drupes harvested from 66 trees in Anuradhapura, Kandy and Kurunegala districts of Sri Lanka were used for characterizing morphological features. For each drupe, seven morphometric data (height, width and weight of drupes, mesocarp thickness, width, height and weight of stones) were measured. Sixty one drupes were used for the quantitative analysis of the epicarp color of drupes. Bitterness, an organoleptic property was analyzed in relation to drupe size by using a taste panel of independent human subjects. The stone traits showed a lower correlation with other drupe traits suggesting that drupe and stone traits may be governed by two separate sets of genes. The cluster analysis based on drupe size traits characterized the $P$. emblica germplasm into four clusters. Number of cells in the mesocarp of smaller and larger fruits was more or less the same but the cell size was larger in larger fruits $(\mathrm{p}<0.05)$. There were significant differences in quantitative color metrics between small and large drupe groups. Thus, $P$. emblica gremplasm has a significantly higher morphological diversity in Sri Lanka but the drupe traits did not vary with respect to their locations or the climate.
\end{abstract}

Keywords: epicarp colour; intraspecific variation; mesocarp cell size

\section{INTRODUCTION}

Phyllanthus emblica L. belongs to the family Phyllanthaceae and is naturalized in Sri Lanka, India and in eastern Asia (Dassanayake and Fosberg, 1988). It is a perennial, deciduous, monoecious tree that can grow up to $15 \mathrm{~m}$ in height. The leaves of $P$. emblica are feathery and glabrous or finely pubescent (Pushpakumara et al., 2007). Fruit is a fleshy drupe (Dassanayake and Fosberg, 1988).

The drupe is the most commercially and medicinally important part of $P$. emblica. The chemical composition of the drupe includes a large variety of hydrolysable tannins and phenolic compounds which are accountable for its medicinal properties (Yang et al., 2012). The presence of ascorbic acid in the drupe accounts predominantly for its antioxidant activity (Scartezzini et al., 2006). Apart from the drupe, the leaves, roots, bark of twigs and the stem are also utilized in a variety of indigenous medicinal products (Pushpakumara et al., 2007). According to ayurvedic medicine, it is one of the few plant species comprising all the five tastes; amla, kasaya, madhura, tikta and katu together in its drupe (The ayurvedic pharmacopoeia of India, 1987). Ethno pharmacological studies reveal that $P$. emblica is used as an indigenous medicinal remedy in 17 countries (Xia et al., 1997). It is largely used to treat diarrhoea, jaundice and inflammations (Krishnaveni and Mirunalini, 2010). The most important formulations made out of $P$. emblica include Cyavanaprasa, Brungamalaka thailaya and Triphala (The ayurvedic pharmacopoeia of India, 1987). For Ayurvedic preparations in Sri Lanka alone, $50,000 \mathrm{~kg}$ of $P$. emblica drupes are imported annually, incurring a cost of over one million rupees (Pushpakumara et al., 2007).

Most importantly, the drupe has a high demand in the fresh fruit market and is commercially used in cosmetic and food industries (cordial, pickle, toffee/candy). P. emblica fruit juice contains the highest vitamin $\mathrm{C}$ content $(4.8 \mathrm{mg} / \mathrm{ml})$ reported for a fruit species, which is also a commercially valuable trait (Khan, 2009). Although P. emblica is still an underutilized fruit crop in Sri Lanka

*Corresponding author's email: sunethss09@gmail.com 
(Pushpakumara et al., 2007), it is a potential cash crop yet to be exploited in mass scale locally.

In Sri Lanka, the morphological and chemical characteristics of fruits of $P$. emblica vary from very small bitter drupes to large, fleshy and less bitter drupes. Since bitterness is proportionate to the amount of hydrolysable tannins and phenolics (Meena et al., 2010) present in the drupe, the smaller drupes are preferred by the indigenous medical industry to develop medicinally important value added products (i.e. Thripala and Brungamalaka thailaya). Due to the preferred use of smaller drupes in indigenous medicine, processing becomes tedious and labour-intensive, where large numbers of small drupes are needed to be de-stoned to extract the pulp. Furthermore, in the fresh fruit market, the larger, fleshy drupes have a high demand. Hence, what seems most logical is that if large P. emblica drupes with very high bitterness can be produced, the industry will be greatly benefited. Here, the diversity of $P$. emblica in Sri Lanka can be exploited to produce an ideotype which is preferred by the indigenous medical industry. Therefore, for such manipulations, it is of prime importance that the diversity of $P$. emblica germplasm in Sri Lanka is morphologically and genetically characterized.

A significant drupe morpho-chemical variability is recorded in the $P$. emblica germplasm in India (Singh et al., 2012). Further, it has been found that the drupe phenolic content and antioxidant activity was attributed to the genotype (Scalzo et $a l .$, 2005). However, the diversity of $P$. emblica germplasm in Sri Lanka has not yet been studied. The aim of this research was to characterize the drupe morphology and bitterness to establish a diversity structure for the $P$. emblica germplasm in Sri Lanka.

\section{MATERIALS AND METHODS \\ Collection of drupes from $P$. emblica germplasm}

The drupes were harvested from $P$. emblica trees growing in the wild or in arboreta in three selected areas of Anuradhapura, Kandy and Kurunegala districts of Sri Lanka during the period from February to April, 2013. Anuradhapura district was categorized as the dry zone whereas the Kandy district was sub-categorized into dry zone [orchard at Digana Ayurvedic Hospital], wet zone [Alupathkada, Gannoruwa, Gatambe, Meewathura (Research and Demonstration Farm, Faculty of Agriculture, University of Peradeniya), Pitakanda, Uduwela, Lewella] and wet-hilly zone [Rikillagaskada]. The Kurunegala district was sub-categorized into dry zone [Ganewatte (Substation, Royal Botanic Garden, Peradeniya)] and wet zone [Dambadeniya]. The sub-categorization of the sampling locations into dry, wet or wet-hilly zones was based on the annual rainfall, elevation and mean annual temperature of the sampling locations (Table 1).

Drupes were harvested from randomly selected mature trees. From each tree, 3-10 mature drupes were randomly harvested. The trees were assigned a tree identification number with reference to sampling location and its climate. Drupes were harvested from 66 trees and a total of 475 drupes were collected.

\section{Evaluation of drupe traits}

For each collected drupe, seven morphometric data, i.e. height, width and weight of drupes, thickness of the mesocarp and, width, height and weight of stones were measured (Figure 1). Height and width were measured using a vernier caliper and the weight was measured using a digital top loading balance.

Table 1: Climatic parameters of sampling locations

\begin{tabular}{lcccl}
\hline Location (District) & $\begin{array}{c}\text { Mean annual } \\
\text { temperature } \\
\left({ }^{\circ} \mathrm{C}\right)\end{array}$ & $\begin{array}{c}\text { Mean annual } \\
\text { rainfall } \\
(\mathrm{mm})\end{array}$ & Climate $^{\mathrm{x}}$ & Agro-climatic region \\
\hline Anuradhapuara & 30.0 & 1250 & Dry & Lowland dry zone \\
Kurunegala & 27.5 & 2000 & Dry & Lowland dry zone \\
Kurunegala & 25.5 & 2500 & Wet & Lowland Intermediate zone \\
Kandy & 25.5 & 2000 & Dry & Midland Intermediate zone \\
Kandy & 20.5 & 2500 & Wet & Midland wet zone \\
Kandy & 20.5 & $2000-2500$ & Wet & Upland wet zone \\
\hline
\end{tabular}

${ }^{\mathrm{x}}$ Climate with respect to average annual rainfall

Source: Department of Meteriology, Sri Lanka, (2014) 
Leaf Color Chart (LCC) for nitrogen deficiency parameters (Rice Research and Development Institute, Bathalagoda) was used for the qualitative measurement of the colour. In addition, for a total of 60 drupes belonging to nine trees, the color of the drupe epicarp was quantitatively measured for darkness/lightness $\left(\mathrm{L}^{*}\right)$, red/green $\left(\mathrm{a}^{*}\right)$ and blue/yellow $\left(\mathrm{b}^{*}\right)$ using a spectrophotometer (CR-10, Konika Minolta, Tokyo, Japan). L* measured the darkness/lightness range of the visual colour from black $\left(-\mathrm{L}^{*}\right)$ to white $\left(+\mathrm{L}^{*}\right)$, a* measured the range from green $\left(-a^{*}\right)$ to red $\left(+a^{*}\right)$ while $b^{*}$ measured the range from blue $\left(-b^{*}\right)$ to yellow $\left(+b^{*}\right)$. The quantitative estimates, $\mathrm{C}^{*}$ (chroma; estimate of dullness/sharpness of the visual color) and $\mathrm{H}^{*}$ (hue angle; estimate of the overall visual color) were calculated using the following equations.

$$
\begin{gathered}
\mathrm{C} *=\sqrt{(a *)^{2}+(b *)^{2}} \\
\mathrm{H} *=\tan ^{-1}\left\{\frac{a *}{b *}\right\}
\end{gathered}
$$

The main organoleptic property of $P$. emblica drupe, i.e., the bitterness, was evaluated in relation to the drupe size by three independent panelists, using a sample of 150 drupes ( 3 drupes each from 50 trees). A bitterness score was assigned as $1=$ mildly bitter, $2=$ moderately bitter and $3=$ awfully bitter. Between each consecutive tasting, a resting period of thirty minutes was allowed to get back the taste buds on the tongue to normal state. The panelists were requested to rinse their mouth with water after tasting each drupe.

\section{Measurement of mesocarp cell number and cell size}

Sample drupes from each tree were preserved in $100 \%$ formalin for histological analyses. The drupes were taken out from formalin, briefly rinsed with distilled water, blotted for a few seconds using a paper towel and cut horizontally into two halves along the diameter (Figure 1; the direction of 'A'). Subsequently, thin radial mesocarp tissue sections (two millimeters or less in thickness) were obtained from epicarp to the stone at the widest diameter of the fruit by handsectioning with a razor blade. The mesocarp tissue sections were immersed in a dilution series of $25 \%, 50 \%$ and $75 \%$ alcohol (30 seconds in each alcohol concentration) and then in the cell wall staining agent, safranin. Overlapping serial images (individual view fields) of the stained tissue sections were captured with a stereo light microscope (BO71, Olympus, Japan) fitted with an analogue camera containing a Kodak Ultramax film roll. The photographic negatives were processed and the photographs were scanned into a computer by using a flatbed document/photo scanner.

Then the images in the individual fields of view were aligned together into one composite image using the software Adobe Photoshop CS3. A reference line was drawn along the length (i.e. radius) of the mesocarp section. All the cells touching the reference line were counted manually, as a representative indicator of the cell number for each fruit. The cell size was calculated by dividing the length of the mesocarp of a drupe by its cell number.

\section{Statistical analysis}

Descriptive statistics of the drupe data were calculated and the normality of each parameter was tested using the Univariate procedure of SAS version 9.1 (SAS Institute, 2009). The drupe parameters which were deviated from the normality were transformed using square root and arc tan transformation methods prior to the statistical analyses and back transformed to original form after the analyses, for interpretation.

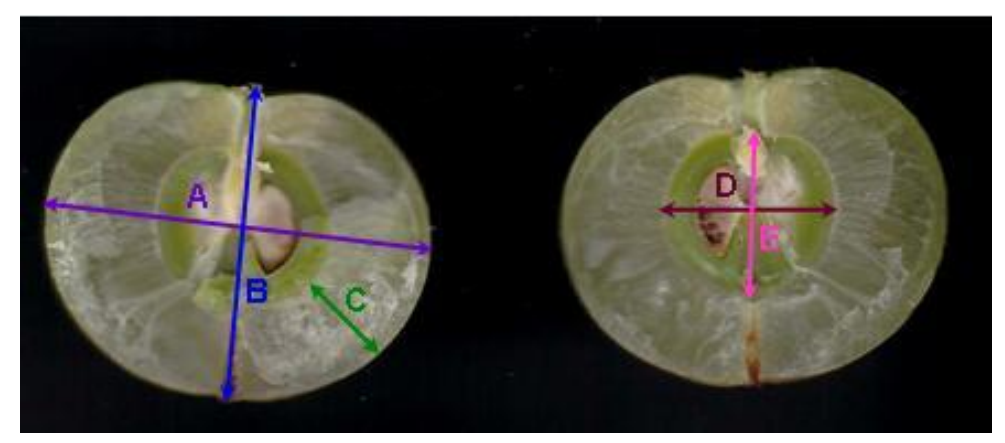

Figure 1. Morphometric measurements of $P$. emblica drupe across a longitudinal section. Cut opened halves of the same drupe are shown. A - width (diameter) of the drupe, B -height of the drupe, C - mesocarp thickness, D - width of the stone and E - height of the stone. 
The frequency distributions of drupe size data were drawn using Minitab 16. Pearson's correlation coefficients for drupe traits including drupe height, width, weight and mesocarp thickness and the stone traits including stone height, width and weight were calculated using the CORR procedure of SAS. A cluster analysis, a multiple regression procedure, was performed for 66 trees with selected drupe size traits, i.e., height, width, weight and mesocarp thickness by having McQuitty linkage, Euclidean distance using MINITAB 16. A dendrogram based on these drupe traits was also constructed. The classification of trees into clusters were further verified by using GLM procedure in SAS, considering individual clusters as the independent variables and drupe size traits as the dependent variables. The drupe size data were also analyzed with reference to the geographic sampling locations using GLM procedure in SAS. The mesocarp cell number and cell size data were analyzed with reference to individual size clusters by using GLM procedure in SAS. The $\mathrm{L}^{*}, \mathrm{a}^{*}, \mathrm{~b}^{*}$, chroma and hue angle data were separately analyzed with reference to large and small groups of trees, to individual clusters and geographical locations using GLM procedure in SAS and followed by cluster analysis having McQuitty linkage, Euclidean distance using MINITAB 16. Chi square analysis was conducted to analyze the sensory data on bitterness using FREQ procedure in SAS and Cramer's V coefficient was used to identify the strength of non-parametric association between fruit size and the bitterness (Kendall and Stuart, 1979).

\section{RESULTS}

\section{Epicarp color in drupes}

The mean $\mathrm{L}^{*}, \mathrm{a}^{*}, \mathrm{~b}^{*}$, chroma and hue angle values were analyzed by pooling large druped clusters and small druped clusters together. The results indicated that the smaller drupes were lighter, yellowish, sharper and less colorful (i.e. dull) than the larger drupes (Table 2). However, qualitative grading of drupe color using Leaf Color Chart (LCC) for nitrogen deficiency parameters (Rice Research and Development Institute, Bathalagoda), proved ineffective in classifying drupe size groups according to color.

The color metric values were also subjected to sampling location-based analysis by using GLM procedure. Drupes from two locations with contrasting climatic features were used for the quantitative color measurements. The drupe color (i.e. hue angle) was similar in fruits from different locations indicating that the fruit color may be independent of the environmental conditions in areas that they grow (Table 3 ).

Table 2. Mean color metric values of large and small classes of P. emblica drupes (fruits)

\begin{tabular}{llllll}
\hline $\begin{array}{c}\text { Drupe } \\
\text { class }\end{array}$ & \multicolumn{1}{c}{$\mathrm{L}^{*}$} & $\mathrm{a}^{*}$ & $\mathrm{~b}^{*}$ & Chroma & Hue angle \\
\hline Large & $-37.82^{\mathrm{Y}} \mathrm{a}^{\mathrm{Z}}$ & $-4.41 \mathrm{a}$ & $11.73 \mathrm{a}$ & $12.66 \mathrm{a}$ & $-21.11 \mathrm{a}$ \\
Small & $-33.52 \mathrm{~b}$ & $-4.96 \mathrm{a}$ & $21.03 \mathrm{~b}$ & $21.64 \mathrm{~b}$ & $-10.86 \mathrm{~b}$ \\
\hline
\end{tabular}

Y Least square means of color metrics

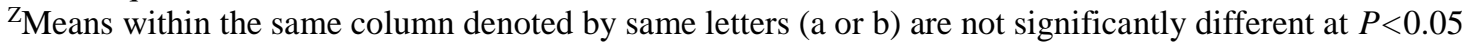
$\mathrm{L}^{*}$ indicates lightness, $+\mathrm{a}^{*}$ indicates redness, $-\mathrm{a}^{*}$ indicates greenness, $+\mathrm{b}^{*}$ indicates yellowness and $-\mathrm{b}^{*}$ indicates blueness. Chroma is the sharpness and hue angle is the true color.

Table 3. Mean color metric values of P. emblica drupes from two selected locations

\begin{tabular}{lccccc}
\hline Location & $\mathrm{L}^{*}$ & $\mathrm{a}^{*}$ & $\mathrm{~b}^{*}$ & Chroma & Hue angle \\
\hline $\begin{array}{l}\text { Anuradhapura } \\
\begin{array}{l}\text { Dry } \\
\text { Kandy Wet } \\
\text { and hilly }\end{array}\end{array}$ & $-34.97^{\mathrm{Y}} \mathrm{a}^{\mathrm{Z}}$ & $-4.80 \mathrm{a}$ & $18.36 \mathrm{a}$ & $19.12 \mathrm{a}$ & $-13.46 \mathrm{a}$ \\
& $-36.37 \mathrm{a}$ & $-4.58 \mathrm{a}$ & $14.40 \mathrm{~b}$ & $15.18 \mathrm{~b}$ & $-18.51 \mathrm{a}$ \\
$\begin{array}{l}\text { Y Least square means of color metrics } \\
\text { Z }\end{array}$ & & & \\
\end{tabular}




\section{Organoleptic properties of $\boldsymbol{P}$. emblica drupes with respect to size}

To investigate the organoleptic property, i.e., bitterness of $P$. emblica, sensory analysis was done in relation to drupe size, where drupes were scored as mildly bitter, moderately bitter and awfully bitter (Table 4). Majority of the larger dupes were mildly bitter (47\% of drupes) whereas the smaller drupes were predominantly awfully bitter (57\% of drupes). In smaller drupes only a few were mildly bitter (9\% of drupes). In larger drupes only a minority was awfully bitter (13\% of drupes).This observation confirmed the general perception that smaller drupes of $P$. emblica are bitterer than the larger drupes. Further, as inferred through the Crarmer's V coefficient, the association between drupe size and the bitterness has no perfect linear relationship (Crarmer's V coefficient is 1 for such a linear strong relationship).

\section{Morphological characterization of $\boldsymbol{P}$. emblica based on drupe traits \\ Frequency distributions}

The frequency distribution of each trait is graphically represented (Figure 2). All the traits followed continuous distributions and the distributions for drupe width, height and mesocarp thickness were left skewed. However, stone traits did not show any particular skewness to larger or smaller sides.

\section{Correlation among drupe traits}

Drupe traits including width, height, weight and mesocarp thickness had a strong significant $(P<0.0001)$ correlation (Pearson's correlation coefficient of 0.88 or more) with each other. However, the stone traits showed lower correlations $(P<0.05)$ with other drupe traits (Table 5). Stone height and stone weight had the least significant correlations with mesocarp thickness ( 0.34 and 0.36 , respectively). No trait showed negative correlation with any other.

\section{Cluster analysis of drupe size traits}

A dendrogram based on McQuitty linkage and Euclidean distance was obtained by analyzing data for highly correlated drupe traits, i.e., width, height, weight and mesocarp thickness for the drupes of 66 trees. P. emblica germplasm was grouped into four clusters at $63.01 \%$ of morphological similarity coefficient (Figure 3). The grouping into four clusters was independently verified by ANOVA (Table 6).

Table 4. Two way contingency table for association analysis of sensory data for bitterness with respect to the size class of $P$. emblica drupes

\begin{tabular}{lccc}
\hline Drupe size category & \multicolumn{3}{c}{ Bitterness score } \\
\cline { 2 - 4 } & Mildly bitter & Moderately bitter & Awfully bitter \\
\hline Large & $47.00 \%^{\mathrm{a}}$ & $40.17 \%$ & $12.82 \%$ \\
Small & $9.09 \%$ & $33.33 \%$ & $57.58 \%$ \\
Chi-Square V & & $32.63 * * * *$ & \\
Cramer's V coefficient & & 00.47 & \\
\hline
\end{tabular}

a Percentage counts in each fruit group, $* * * P<0.0001$

Table 5: Pearson's correlation coefficients among drupe and stone size traits of P. emblica

\begin{tabular}{lcccccc}
\hline & $\begin{array}{c}\text { Fruit } \\
\text { height }\end{array}$ & $\begin{array}{c}\text { Fruit } \\
\text { weight }\end{array}$ & $\begin{array}{c}\text { Mesocarp } \\
\text { thickness }\end{array}$ & $\begin{array}{c}\text { Stone } \\
\text { width }\end{array}$ & $\begin{array}{c}\text { Stone } \\
\text { height }\end{array}$ & $\begin{array}{c}\text { Stone } \\
\text { weight }\end{array}$ \\
\hline Fruit width & $0.92 * * *$ & $0.94 * * *$ & $0.93 * * *$ & $0.70 * * *$ & $0.44 * *$ & $0.4 * * *$ \\
Fruit height & & $0.91 * * *$ & $0.86 * * *$ & $0.72 * * *$ & $0.54 * * *$ & $0.54 * * *$ \\
Fruit weight & & & $0.88^{* * *}$ & $0.75 * * *$ & $0.48^{* * *}$ & $0.61 * * *$ \\
Mesocarp thickness & & & & $0.56 * * *$ & $0.34 *$ & $0.36 * *$ \\
Stone width & & & & & $0.69 * * *$ & $0.72 * * *$ \\
Stone height & & & & & $0.68^{* * *}$ \\
\hline
\end{tabular}



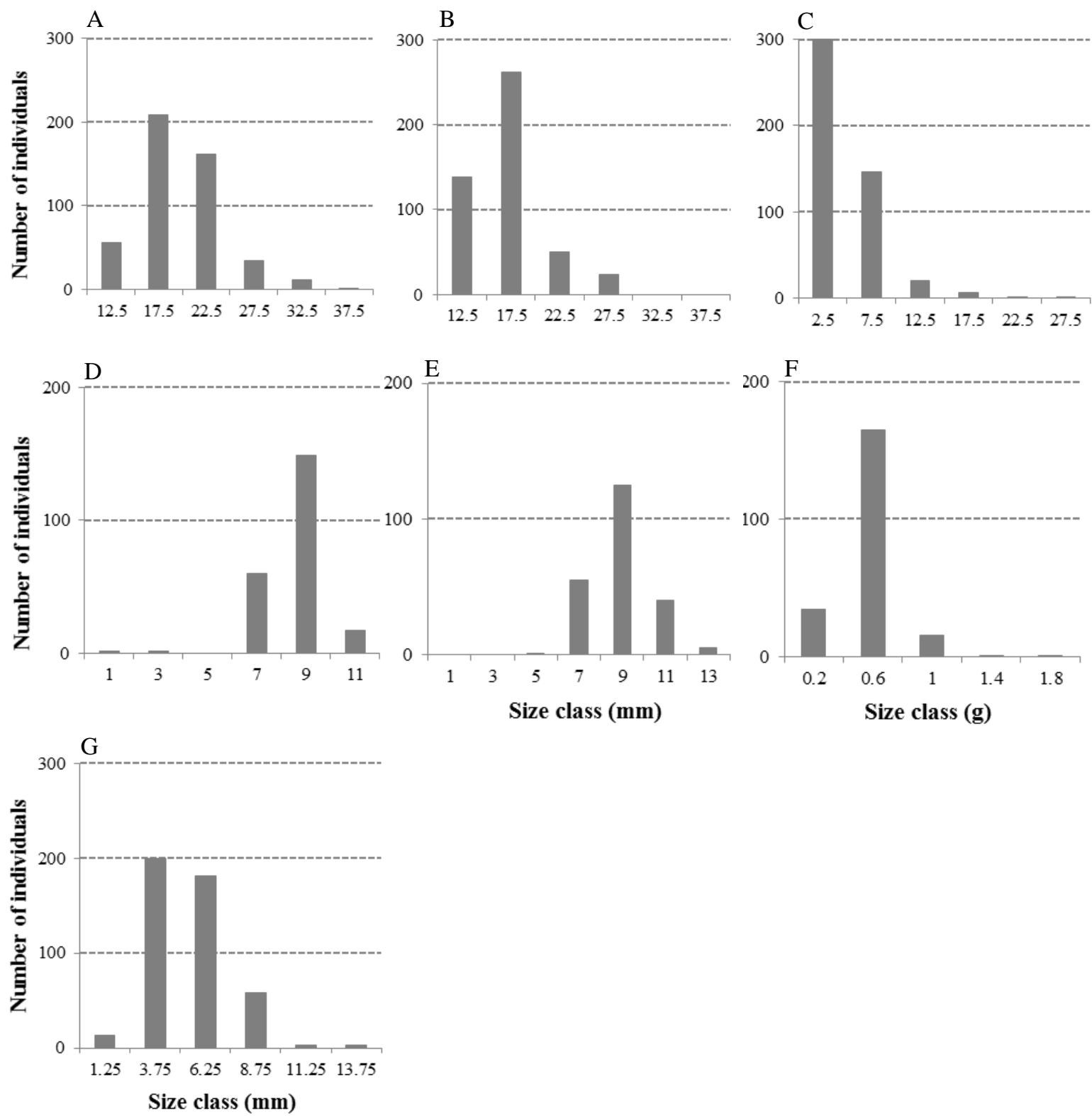

Figure 2. Frequency distributions of drupe traits in P. emblica. A - Drupe width (mm), B - Drupe height (mm), C - Drupe weight (g), D - Stone width (mm), E - Stone height (mm), F- Stone weight (g), G - Mesocarp thickness $(\mathrm{mm})$. Vertical axis of each graph represents the number of individuals and horizontal axis of each graph represents the mid value of phenotypic class intervals.

The mean values for drupe height, width, weight and mesocarp thickness showed a significant $(P<0.05)$ differences among the four clusters. The Cluster 4 (largest group) comprised the trees with the highest mean values for drupe width, height, weight and mesocarp thickness and Cluster 3 (smallest group) comprised the trees with the smallest mean values for drupe height, width, weight and mesocarp thickness. Cluster 2 (smaller group) and Cluster 1 (larger group) comprised trees with intermediate values for mean drupe traits, where Cluster 2 was biased towards the trees with smaller drupes and Cluster1was biased towards the trees with larger dupes (Table 3). Images of representative drupes from each cluster are given with size comparison using a US dime (Figure 4). 


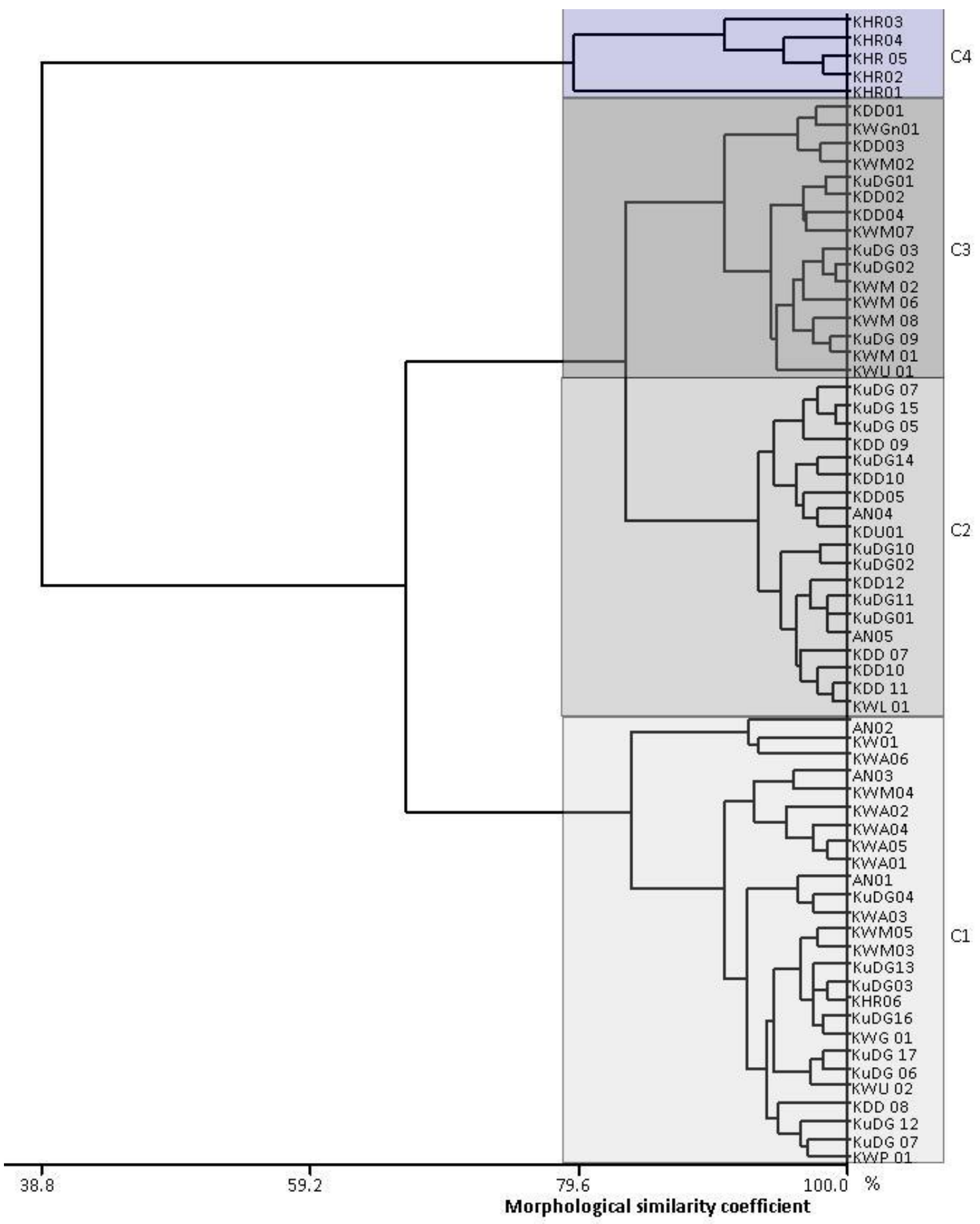

Figure 3. Dendrogram representing fruits of $66 \mathrm{P}$. emblica trees from different locations. The tree was clustered based on drupe traits, namely, fruit height, width, weight and mesocarp thickness. Four clusters were identified at $63.01 \%$ of morphological similarity coefficient. The clustering was independently verified by using parametric statistics (i.e. ANOVA) and the cluster effect was significant $(P<0.05) . \mathrm{C} 1, \mathrm{C} 2, \mathrm{C} 3$ and C4 are Clusters (Table 6). [KHR-Kandy Hilly Rikallagaskada, KWGn-Kandy wet Gannoruwa, KWMKandy wet Mewathura, KWG-Kandy wet Gatambe, KWA-Kandy wet Alupathakada, KWL-Kandy wet Lewella, KWP-Kandy wet Pitakanda, KWU-Kandy wet Uduwela, KDD-Kandy dry Digana, KuDGKurunegala dry Ganewatte, KuW- Kurunegala wet, An-Anuradhapura]. 
Table 6: Mean drupe trait values of $P$. emblica drupes belonging to four clusters (as in Figure 3)

\begin{tabular}{lcccc}
\hline Cluster & $\begin{array}{c}\text { Drupe height } \\
(\mathrm{cm})\end{array}$ & Drupe width $(\mathrm{cm})$ & Drupe weight $(\mathrm{g})$ & $\begin{array}{c}\text { Mesocarp thickness } \\
(\mathrm{mm})\end{array}$ \\
\hline 1 (Larger) & $18.99^{\mathrm{x}} \mathrm{a}^{\mathrm{z}}$ & $22.20^{\mathrm{y}} \mathrm{a}^{\mathrm{z}}$ & $05.98 \mathrm{a}$ & $06.66 \mathrm{a}$ \\
2 (Smaller) & $16.10 \mathrm{~b}$ & $18.40 \mathrm{~b}$ & $03.59 \mathrm{~b}$ & $04.87 \mathrm{~b}$ \\
3 (Smallest) & $13.59 \mathrm{c}$ & $15.44 \mathrm{c}$ & $02.13 \mathrm{c}$ & $03.57 \mathrm{c}$ \\
4 (Largest) & $27.05 \mathrm{~d}$ & $30.42 \mathrm{~d}$ & $14.21 \mathrm{~d}$ & $10.01 \mathrm{~d}$ \\
\hline
\end{tabular}

${ }^{\mathrm{x}}$ Least square means for mesocarp cell number

${ }^{\mathrm{x}}$ Least square means for mesocarp mean cell diameter

${ }^{\mathrm{Z}}$ Means within the same column denoted by same letters are not significantly different at $P<0.05$
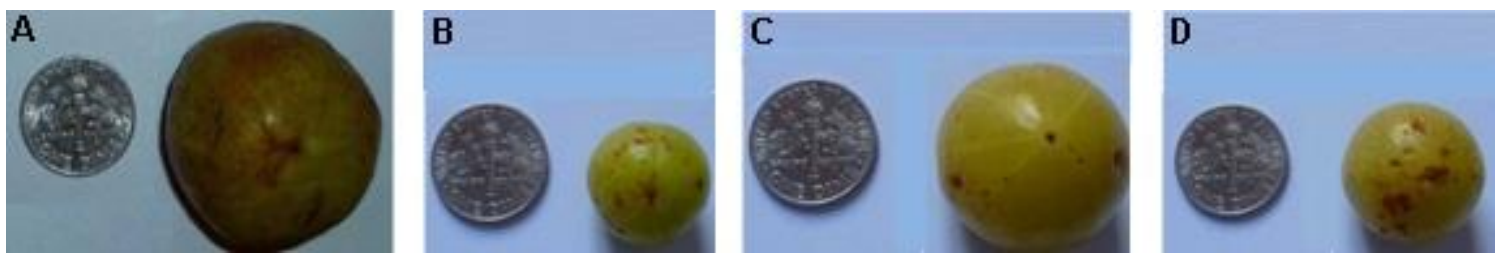

Figure 4. Representative fruits belonging to four clusters (Fig. 3) based on drupe traits, in comparison with the size of a US dime (coin) on the left side of each drupe. (A) Cluster 4, (B) Cluster 2, (C) Cluster 1, (D) Cluster 3.

\section{Histological analysis of mesocarp cell number and cell size in relation to drupe size}

Among the four clusters based on drupe size traits (Figure 3), the radial mesocarp cell number across a transverse section of a drupe, did not show a significant variation $(P<0.05)$, whereas the cell size appeared to be varied dramatically (Table 7). The larger drupes belonging to Cluster 4 had relatively larger cells in contrast to the other three clusters.

\section{Drupe size traits in relation to the climate of sampling locations}

The mean traits of drupes collected from Anuradhapura and Kurunegala (wet) were not significantly different $(P>0.05)$. In addition, drupe dimensions and weight of drupes collected from Kandy (wet) and Kurunegala (dry) were not significantly different $(P>0.05)$. However, mesocarp thickness of drupes in Kandy (wet) was significantly higher than (by 22\%) that of the drupes from Kurunegala (dry) (Table 8). In summary, there was no direct relationship of drupe size traits with the sampling location. The coefficient of variation from sampling location ranged from $0.28-0.45$ for drupe traits, implying that the environmental influence on drupe development is less compared to the impact of other factors such as genetics.

\section{DISCUSSION}

The morphological characterization of drupes of $P$. emblica revealed high diversity that exists within this species. Even though the analysis was based on the naturally available germplasm without creating controlled genetic populations, the randomness of the tree and sample selection enabled the assessment of the phenotypic pattern of the drupe traits. It is clear from the frequency distributions that drupe traits are governed by polygenes and the low correlation observed between drupe and stone traits implies that two independent genetic mechanisms should exist for their determination. Out of the total phenotypic variability of drupe traits, a maximum of $45 \%$ is controlled by environmental factors. According to our analysis, at least $55 \%$ of the phenotypic variability is controlled by non-environmental factors as genetics. This will provide a strong basis for higher heritability in drupe traits and encourage breeding and mapping of the genes associated. The stone size is independent of its drupe size, implying that the stone provides uniform sized space for seeds inside regardless of the drupe size. This is also in parallel with our observation of negligible variability in seed size, viz. regardless of the drupe size, seeds require fixed stone space for their development. 
Table 7. Mean mesocarp cell number values of $P$. emblica drupes belonging to four clusters (as in Figure 3)

\begin{tabular}{ccc}
\hline Cluster & Mesocarp cell number & Mean diameter of mesocarp cells (mm) \\
& & \\
\hline 1 & $45^{\mathrm{x}} \mathrm{a}^{\mathrm{z}}$ & $0.15^{\mathrm{y}} \mathrm{a}^{\mathrm{z}}$ \\
2 & $41 \mathrm{a}$ & $0.12 \mathrm{~b}$ \\
3 & $40 \mathrm{a}$ & $0.09 \mathrm{c}$ \\
4 & $42 \mathrm{a}$ & $0.24 \mathrm{~d}$ \\
\hline
\end{tabular}

${ }^{x}$ Least square means for mesocarp cell number

${ }^{y}$ Least square means for mesocarp mean cell diameter

${ }^{\mathrm{Z}}$ Means within the same column denoted by same letters are not significantly different at $P<0.05$

Table 8. Mean trait values of $P$. emblica drupes (fruits) collected from different locations with respect to climatic conditions

\begin{tabular}{llllll}
\hline Location (District) & Climate $^{\mathrm{x}}$ & $\begin{array}{l}\text { Fruit } \\
(\mathrm{mm})\end{array}$ & $\begin{array}{l}\text { Fruit height } \\
(\mathrm{mm})\end{array}$ & $\begin{array}{l}\text { Fruit } \\
\text { weight }(\mathrm{g})\end{array}$ & $\begin{array}{l}\text { Mesocarp } \\
\text { thickness }(\mathrm{mm})\end{array}$ \\
\hline Anuradhapuara & Dry & $21.27^{\mathrm{Y}} \mathrm{a}^{\mathrm{Z}}$ & $18.57 \mathrm{a}$ & $5.75 \mathrm{a}$ & $5.86 \mathrm{a}$ \\
Kurunegala & Dry & $19.35 \mathrm{~b}$ & $16.43 \mathrm{~b}$ & $3.95 \mathrm{~b}$ & $4.77 \mathrm{~b}$ \\
Kurunegala & Wet & $22.29 \mathrm{a}$ & $19.37 \mathrm{a}$ & $6.29 \mathrm{a}$ & $6.85 \mathrm{a}$ \\
Kandy & Dry & $17.44 \mathrm{c}$ & $14.94 \mathrm{c}$ & $3.09 \mathrm{c}$ & $4.36 \mathrm{~b}$ \\
Kandy & Wet & $27.56 \mathrm{~d}$ & $23.69 \mathrm{~d}$ & $11.50 \mathrm{~d}$ & $8.46 \mathrm{c}$ \\
Kandy & Wet & $19.78 \mathrm{~b}$ & $16.64 \mathrm{~b}$ & $4.53 \mathrm{~b}$ & $5.82 \mathrm{a}$ \\
\hline Coefficient of & & 0.37 & 0.30 & 0.45 & 0.28 \\
variation & & & & \\
\hline
\end{tabular}

${ }^{\mathrm{x}}$ Climate with respect to dryness/wetness (i.e. rainfall) (Table 1)

${ }^{\mathrm{Y}}$ Least square means for drupe traits

${ }^{\mathrm{Z}}$ Means within the same column denoted by same letters are not significantly different at $P<0.05$

The hierarchical cluster analysis is widely used to characterize the germplasms of other species such as sweet cheery diversity in South East Serbia (Mratinic et al., 2012). However, declaring number of clusters from the dendrogram is a subjective and dubious decision. In order to overcome that issue, we used parametric statistical method (i.e. ANOVA) to show that mean values of the traits in resultant clusters are significantly different. If any of the trait has mean values not significantly different among clusters, the clustering has to be less accurate. Therefore, we propose the strategy of independent verification of selected clusters using parametric statistical methods like ANOVA for research involving the characterization of biological diversity.

The size of the drupe seems to have a correlation with the mesocarp cell size rather than the mesocarp cell number. It has been reported in early studies that, the increase in cell number of the mesocarp correspond to the increase of drupe size of different cultivars. This phenomenon is true for small and large cultivars of peach (Scorza et al., 1991), sweet cherry (Olmstead and Iezzoni, 2007 and Zhang et al., 2010) and rabbit eye blueberry (Johnson et al., 2011). But according to the results $P$. emblica drupe size varies with cell size which is similar to the case of tomatoes. It has been shown that tomato fruit cell size has a strong positive correlation with ploidy level (Cheniclet et al., 2005). Likewise $P$.emblica might also have a ploidy difference related with drupe size that requires further cytogenetic analysis.

The drupe size difference is not directly correlated with the amount of moisture available in the soil (Goldhamer et al., 1999). Dry climates with less rainfall or wet climates with higher rainfall seem to be not directly governing the fruit size indicating the significance of genetic predisposition on fruit size. However, the samples obtained from Kandy-wet-hilly region had biggest fruits but it is pretty immature to conclude that whether it is due to the advertent selections of germplasm or due to more conducive climate 
for the fruit development. It has been shown from early studies that $P$. emblica drupe width and height are influenced by environmental conditions (Singh et al., 2012).

The color variability of $P$. emblica drupes is too narrow so that qualitative color grading systems are not adequate to capture the available diversity. However, $\mathrm{L}^{*}, \mathrm{a}^{*}, \mathrm{~b}^{*}$, chroma and hue angle based on spectrophotometry can be effectively used to capture slight color variations. In sweet cherry, a similar approach has successfully been used to map the Quantitative Trait Loci (QTLs) and to identify the candidate genes for drupe color (Sooriyapathirana et al., 2010). In P. emblica, small and large drupes have significantly different $\mathrm{L}^{*}, \mathrm{~b}^{*}$, chroma and hue angle indicating a certain correlation between size and color traits.

The greenness infers to the amount of chlorophyll available and it is proportionate to the microclimatic conditions such as light intensity (Leong and Anderson, 1984). Drupes would be less green in low light intensities (under shade) due to redistribution of chlorophyll to plant organs that receive sunlight thus having the ability to participate in photosynthesis. Greenness of the variety, 'Granny Smith' apples varies in the same manner with variable light environments (Hirst et al., 1990). Chroma also varies based on the micro environmental conditions as shade (Hoppula and Karhu, 2006).

The bitterness of drupes is a result of tannins; hydrolysable Emblicanin A and B (Meena et al., 2010). In the mouth, Emblicanin A is hydrolyzed in to gallic acid (a phenolic compound) which causes bitterness (Meena et al., 2010). The differences in bitterness between two groups indicated differences in content of drupe phenolics. The drupe phenolic content is predominantly governed by plant genotype (Scalzo et al., 2005) which indicates that $P$. embilica in Sri Lanka may be genetically variable. However, our results are inconclusive to infer that small drupes are awfully bitter and large drupes are mildly bitter.

In summary, these results showed that $P$. emblica germplasm in Sri Lanka shows a significantly high diversity in relation to drupe size, epicarp color and bitterness and, the diversity of these characters can be due to the genetic variation. Further studies are required to assess the diversity of the species using molecular markers, DNA sequencing and chemical composition analysis.

\section{ACKNOWLEDGMENTS}

Authors wish to acknowledge the University of Peradeniya Research Grant RG/2013/15/S for funding, the Department of Crop Science, Faculty of Agriculture, University, Peradeniya, Sri Lanka, the Royal Botanic Gardens, Peradeniya, Sri Lanka, Ayurvedic Hospital, Digana, Sri Lanka for providing some plant material for this study.

\section{REFERENCES}

Cheniclet, C., Rong, W.Y., Causse, M., Frangne, N., Bolling, L., Carde, J.P. and Renaudin, J.P. (2005). Cell expansion and endoreduplication show a large genetic variability in pericarp and contribute strongly to tomato fruit growth. Plant Physiology 139: 1984- 1994

Dassanayake, M. D. and Fosberg, F. R. (1988). A Revised Hand Book of the Flora of Ceylon. New Delhi: Oxford and IBH Publishing Co. Pvt. Ltd. 19: 219-220

Department of Meteorology, Sri Lanka. (2014) Climatic data available at http://www.meteo.gov.lk/, accessed on June 14,2014

Goldhamer, D. A., Fereres, E., Mata, M., Girona, J., Cohen, M. (1999). Sensitivity of continuous and discrete plant and soil water status monitoring in peach trees subjected to deficit irrigation. Journal of the American Society for Horticultural Science 124: 437444

Haston, E., Richardson, J. E., Stevens, P. F., Chase, M.W. and Harris, D.J. (2009). The linear Angiosperm Phylogeny Group (LAPG) III: a linear sequence of the families in APG III. Botanical Journal of the Linnean Society 161: $128-131$

Hirst, P. M., Tustin, D. S. and Warrington, I. J. (1990). Fruit color responses of "Granny Smith" apple to variable light environments. New Zealand Journal of Crop and Horticultural Science 18: 205-214

Hoppula, K. B. and Karhu, S.T. (2006) Strawberry fruit quality responses to the production environment Journal of Food, Agriculture and Environment 4: 166-170

Johnson, L. K., Malladi, A. and NeSmith, D. S. (2011). Differences in cell number facilitate fruit size variation in rabbiteye blueberry genotypes. Journal of American Society of Horticultural Sciences 136: 10-15 
Kendall, M. and Stuart, A. (1979). The advanced theory of statistics. $4^{\text {th }}$ Edition. Charles Griffin London. 2: p588

Khan, K.H. (2009). Role of Emblica officinalis in medicine. Botanical Research International 2: $218-228$

Krishnaveni, M. and Mirunalini, S. (2010). Therapeuticpotential of Phyllanthus emblica (amla): the ayurvedic wonder. Journal of Basic and Clinical Phyisiology and Pharmacology 21: 93-105

Leon, T. Y. and Anderson, J. M. (1984). Adaptation of the thylakoid membranes of pea cholorplasts to light intensities. I. Study on the distribution of chlorophyll-protein complexes. Photosynthesis Research 5: 105115

Meena, A. K., Singh, A. and Rao, M. M. (2010). Evaluation of physicochemical and preliminary phytochemical studies on the fruit of Emblica officinalis Gaertn. Asian Journal of Pharmaceutical and Clinical Research 3: 242-243

Mratinic, E., Aksic, M. F. and Jovkovic, R. (2012). Analysis of wild sweet cherry (Prunusavium L.) germplasm diversity in South-East Serbia. Genetica 44: 259- 268

Olmstead, J. W. and Iezzoni, A. F. (2007). Genotypic Differences in Sweet Cherry Fruit SizeAre Primarily a Function of Cell Number. Journal of American Society of Horticultural Sciences 132: 697-703

Pushpakumara, D. K. N. G. and Heenkenda, H. M. S. (2007). Nelli (Amla) Phyllanthus emblica L. In: Pushpakumara, D. K. N. G., Gunasena, H. P. M. and Singh, V. P. (eds) Underutilized fruit trees in Sri Lanka. Volume 1. World Agroforestry Centre, South Asia Office, New Delhi, India. Chapter 6: 180-221

Scalzo, J., Politi, A., Pellegrini, N., Mezzetti, B. and Battino, M. (2005). Plant genotype affects total antioxidant capacity and phenolic contents in fruit. Nutrition 21: $207-$ 213

Scartezzini, C., Antognoni, F., Raggi, M.A., Poli, F. and Sabbioni, C. (2006). Vitamin C content and antioxidant activity of the fruit and of the Ayurvedic preparation of Emblica officinalis Gaertn. Journal of Ethnopharmcy 104: 113-118

Scorza, R., May, L. G., Purnell, B. and Upchurch, B. (1991).Differences in number and area of mesocarp cells between small and large fruited peach cultivars. Journal of American Society of Horticultural Sciences 116: 861864

Singh, B., Uniyal, A. K., Rawat, S. M. and Rana, D.K. (2012). Estimation of genetic variability in Phyllanthus emblica L. Towards a contribution in sustainable rural development. Journal of Horticulture and Forestry 4: 92-95

Sooriyapathirana, S. S., Khan, A., Sebolt, A. M., Wang, D., Bushakra, J.M., Kui Lin-Wang, Allan, A. C., Gardiner, S. E., Chagné, D. and Iezzoni, A.F. (2010). QTL analysis and candidate gene mapping for skin and flesh color in sweet cherry fruit (Prunus avium L.). Tree Genet Genomes 6:821-832.

The Ayurvedic pharmacopoeia of India. (1987) Government of India Ministry of Health and Family Welfare, Department of Indian Systems of Medicine and Homoeopathy 1: 45.

Xia, Q., Xiao, P., Wan, L. and Kong, J. (1997). Ethnopharmacology of Phyllanthus emblica. L. China journal of Chinese materia medica 22: $515-518$

Yang, B., Kortesniemi, M., Liu, P., Karonen, M. and Salminen, J. P. (2012). Analysis of hydrolyzable tannins and other phenolic compounds in emblic leaf flower (Phyllanthus emblica L.) fruits by high performance liquid chromatographyelectrospray ionization mass spectrometry. Journal of Agriculture and Food Chemistry 60: $8672-8683$.

Zhang, G., Sebolt, A. M., Sooriyapathirana, S. S., Wang, D., Bink, M.C.A.M., Olmstead, J. W. and Iezzoni, A. F. (2010). Fruit size QTL analysis of an $F_{1}$ population derived from a cross between a domesticated sweet cherry cultivar and a wild forest sweet cherry. Tree Genetics and Genomes 6:25-36. 